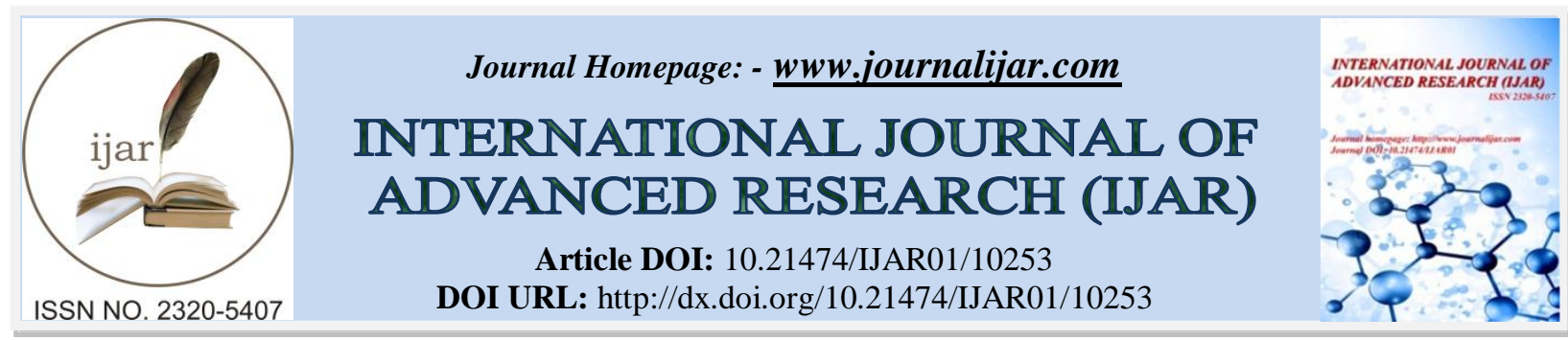

RESEARCH ARTICLE

\title{
PREVENTION OF ADMINISTRATIVE OFFENCES INFRINGING THE PROTECTION OF PUBLIC ORDER
}

\author{
Akhmedova Sorahon Talibjanovna
}

\section{Manuscript Info}

Abstract

Manuscript History

Received: 14 October 2019

Final Accepted: 16 November 2019

Published: December 2019

\section{Introduction:-}

In accordance with the Strategy for the Further Development of the Republic of Uzbekistan in 2017-2021, one of the priority areas is the improvement of the system of combating crime and preventing offences.

As the head of our state noted, the employees of the internal affairs agencies should work in such a way that the people are happy with the state. It is this demand that serves as the basis and purpose of the reforms undertaken and ongoing in the field.

The main criterion for the activities of the staff of the internal affairs agencies was the service of the interests of the people. In this direction, the internal affairs authorities must ensure that public order and public security are reliably maintained.

In order to bring the internal affairs agencies closer to the population, provide them with timely and quality services, solve problems affecting citizens on the spot, ensure systematic and targeted fight against crime and prevent offences in remote settlements, additional offices and team sites have been established.

In this direction, the internal affairs agencies should ensure that public order, the rights and legitimate interests of citizens are protected from unlawful acts, that they are promptly and fully disclosed, and that they identify and fully assist in eliminating the causes and conditions conducive to the commission of unlawful acts.

Information and communication technologies are being introduced in the area of public order and security. A centralized video surveillance system has been established in the capital, major cities and districts. Such projects have had good results in preventing offences, solving crimes and ensuring a stable situation.

Thus, practice shows that most administrative offences in the field of public order and public security are committed on the streets and other public places. Therefore, a great deal of work on prevention and suppression is carried out by the internal affairs agencies.

In accordance with the Presidential Decision on measures for the fundamental improvement of the activities of the crime prevention units of the internal affairs agencies, the most important task of the Ministry of Internal Affairs and its territorial units is to organize preventive work in close cooperation with the population, Citizens 'self-government bodies and other civil society institutions directed primarily by To ensure early prevention of offences, to enhance 
the legal culture in society, Instilling in citizens respect for the law and intolerance of all manifestations of violations of the law.

In accordance with article 7 of the Administrative Liability Code, State bodies, citizens 'self-government bodies and voluntary associations develop and carry out measures aimed at preventing administrative offences, identifying and eliminating the causes and conditions conducive to their commission, educating citizens in a spirit of consciousness, discipline and compliance with the Constitution and the laws of the Republic of Uzbekistan.

The prevention and suppression of administrative offences is determined by the specific legal nature of the particular offence and the conditions for its commission. As a rule, most administrative offences are committed in priority, which means that the internal affairs officer must create a positive background among the population to prevent and suppress administrative offences.

The Administrative Liability Code contains a chapter on administrative liability for offences that infringe on public order, such as minor hooliganism; The appearance of citizens in public places in religious clothes; The illicit manufacture, possession, import or distribution of religious materials, the manufacture, storage or distribution of materials; Propagating national, racial, ethnic or religious enmity; Shooting with firearms in violation of the established order; Illicit trafficking in fireworks; Manufacture for the purpose of marketing or sale by citizens of strong alcoholic beverages of home production; illegal production or turnover of ethyl alcohol, alcoholic and tobacco products; Alcohol consumption in public places; Involving a minor in antisocial behaviour; Involving a minor in the commission of an administrative offence; begging; Allowing a minor to stay in places of entertainment (leisure) at night; Production, import, distribution, advertising, demonstration of pornographic products; Manufacture, import, distribution, advertising, display of products promoting the cult of violence or cruelty; occupation prostitution; Gambling and other risk-based games; Violation of requirements to combat domestic noise.

Thus, when persons who commit administrative offences are identified, an officer of the internal affairs agencies, when deciding to detain and deliver the offender, must take into account, in accordance with articles 284,286 of the

\section{Administrative Liability Code:-}

1. The person of the offender and the possible dangerous consequences if he is not detained;

2. Possible difficulties in detention, which may arise if the offender;

3. Possibility of armed resistance or attack;

4. Grounds and procedure for the use of special means and physical force.

As noted by the foreign scientist Ivanov A.K. the activity of the internal affairs agencies to prevent and suppress administrative offences requires from employees perseverance, resistance, courage, self-control, high professionalism and determination.

According to Bahrah D.N., prevention and prevention of offences as a set of measures aimed at identifying, limiting or eliminating the conditions of offences in general and their certain types, the social danger of the offender 's personality, is the most effective way to combat offences, primarily because it ensures the identification and elimination of their origins. To a large extent, it is the prevention of the very possibility of committing offences. In the prevention of offences, criminal factors can be targeted and mediated when they have not yet gained force. The prevention of offences makes it possible to address them in the most humane ways, at the least cost to the State and society.

When detaining an offender, an internal affairs officer must remember that, in accordance with article 25 of the Constitution, everyone has the right to liberty and security of person.

It should be noted that public order is an important element of the legal basis for citizens 'activities. It includes a system of social relations, which arises and develops in the process of communication of its participants mainly in public places and is regulated by legal and social norms, observance of which ensures personal and public safety of people, environment of tranquillity of public life.

Thus, the internal affairs authorities, exercising their powers to prevent offences, should implement them through the use of criminological analysis with a view to developing a plan of action for the successful elimination of 
emerging criminal situations. In order to successfully implement the prevention tasks, staff should have not only a concept but also a clear and complete understanding of the mechanism of the impact of specific local conditions on the number, nature and structure of offences in the region.

The prevention and prevention of administrative offences that infringe on the protection of public order is a strategic direction in the system of measures taken by the State to strengthen the rule of law. It is the most effective way to combat crime, primarily because it identifies and eliminates its origins. To a large extent, it is the prevention of the very possibility of committing offences. In the prevention of offences, criminal factors can be targeted and mediated when they have not yet gained force. At the same time, the arsenal of means of preventing offences allows to interrupt the planned or started illegal activities, to prevent the occurrence of harmful consequences of attacks. The prevention of offences makes it possible to solve the problems of combating them in the most humane ways, at the least cost to the State and society.

\section{Literature:-}

1. Constitution of the Republic of Uzbekistan. T. 2018

2. Presidential Decree No. УП-4947 of 7 February 2017 on the Strategy for the Further Development of the Republic of Uzbekistan

3. Administrative Liability Code. T., 2019.

4. Presidential Decision No. ПП-2896 of 18 April 2017 on measures for the fundamental improvement of the activities of the crime prevention units of the internal affairs agencies.

5. Ivanov A.K. Personal safety of employees of internal affairs agencies. Irkutsk, 2014 S. 95.

6. Bahrah D.N. Types of administrative coercion//Problems of improvement of legislation on administrative liability. M, 2010. Page 56. 